\title{
In Guatemala, They Stripped Us the Right to Life but Also the Right to Die. Forty-Five Thousand Persons Disappeared and Detaineid by the State of Terror
}

\author{
Alberto Fuentes-Rosales \\ Guatemala's National Police \\ Historical Archive \\ Received: November $11^{\text {th }}, 2016$ \\ Accepted: December 10 $0^{\text {th }}, 2016$
}

\begin{abstract}
This text presents an analysis of the systematic terror of State put in practice in Guatemala against its population through kidnapping, disappearance and forced detention, and the processes the Archivo Histórico (Historical Archives) is leading in the country to exhume, identify and denounce these genocide facts.
\end{abstract}

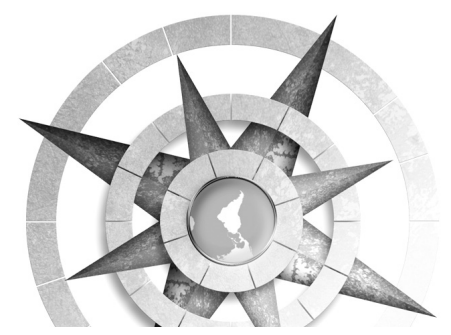

Keywords: Historical Archives of Guatemala, genocide in Guatemala, terror of State, forced disappearance, detention and torture in Guatemala.

\section{Resumen}

Se presenta un análisis del sistemático terror de Estado ejercido por Guatemala en su población mediante secuestro y la desaparición-detención forzada y de los procesos que lleva adelante el Archivo Histórico de dicho país en la exhumación, identificación y denuncia de estos hechos genocidas. 


\section{Resumo}

O terror de Estado exercido por Guatemala em sua população mediante seqüestro, desaparecimento forçado e detenção de pessoas e os processos que está sendo realizado pelo Arquivo Histórico do país na exumação, identificação e reporte desses fatos genocidas são analisados neste artigo.

Palavras chave: Arquivo Histórico de Guatemala, genocídio, terrorismo de Estado, desaparecimento forçado, detenção e tortura na Guatemala

- On June 21, 1980, members of the Policía Nacional (National Police) kidnapped 27 trade union leaders who were holding a meeting at the Central Nacional de Trabajadores (National Centre of Workers). The leaders celebrated the meeting at their headquarters in Guatemala City's downtown. At present, there is no news of these people.

- On August 24 of the same year, 17 unionists were kidnapped; they were gathered at Emaús Church, located at 40 kilometers from Guatemala City. Neither is there news on these people.

- According to the report of the Comisión para el Esclarecimiento Histórico (Commission for Historical Clarification), $\mathrm{CEH}$, the internal armed conflict in Guatemala left more than 200,000 victims, including more than 45,000 detained and disappeared people.

- The actions of political violence are attributable as follows: $93 \%$ to the State, $3 \%$ to the guerrilla groups, and $4 \%$ to unknown agents.

- Regarding the victims, $11 \%$ were girls and boys, meaning that 22,000 children were equally killed or disappeared in those terrible years.

- In a property of the former military zone of Cobán, north of the country, the Fundación de Antropología Forense de Guatemala (Foundation of Forensic Anthropology of Guatemala), (FAFG) has exhumed 565 bones to date. In the grave \#13, the remains of 45 girls and boys, some still of very young age, were found. From the identification of some of these bones, it was determined that these children were survivors of the massacres the army committed in Rio Negro, Rabinal. This is called genocide in every part of the world.

- To this date, through the scientific analysis of these bones, the FAFG has identified 138 people. All of them were victims of forced disappearance committed by the army.

- The state of terror that Guatemala suffered in those years led to the decision of not identifying the victims. After having suffered the 
terrible experience of abduction, cruel tortures and, finally, extrajudicial executions, these people were abandoned in solitary places and when these corpses were located they were transferred to the Cemetery La Verbena, where they were buried as "NN".

- On that cemetery, located in Guatemala City, the FAFG has exhumed 20,250 bones of people who were buried without proceeding to their identification as stated by law.

- These were some ways of how the State of terror tried to conceal what was happening to the country.

- Thirty years of absolute impunity, frustration and hopelessness has passed; but these thirty years have also been a time of accumulation and learning. Organizations of victims' relatives have learned how to deal with the State justice. And in recent years, we have had the Office of Public Prosecutor committed to justice; as well as brave and professional judges and prosecutors who have made trials progress further in the last five or six years, a lot more than in the previous thirty years.

- On July 2005, when the atmosphere of impunity still prevailed, documentation was found in the National Police Historical Archive (AHPN). The procedure that has been carried out with this documentation for a little more than 11 years has become an important factor contributing substantively to the process of access to the truth, historical memory and justice: rights that historically have been denied to the people of Guatemala.

- The AHPN holds the information generated and received by the $\mathrm{Na}$ tional Police during its 116 years of existence, from 1881 to $1997-$ in this year the institution was dissolved within the framework of Peace Accords, and was accused of serious violations to human rights, impunity and corruption. The information consisted of 57 million pages.

- The army orchestrated a counter-insurgency and terror policy which was established in the country during those years, more significantly between 1975 and 1985 . The army also assigned to the National Police a specific role that basically consisted on operations carried out in urban areas, particularly in Guatemala City.

- In the Criminological Investigations Department of the National Police were found more than 1200000 cards; they register forms of control and surveillance of people from 1935 to 1986.

- The documents found were kept with the best conditions of orga- 
nization and conservation. The cards were ordered alphabetically, and this shows us the logic of an agile procedure to locate information of institutional interest almost immediately.

- In the 80's, Guatemala had about 8 million inhabitants. If we assume that half of this population consisted of underage people, these documents showed that the National Police had registration on $30 \%$ of the country's adults; thousands of them considered as "internal enemies" as the army called them.

- When the wave of terror came, most of these political opponents were killed or detained and disappeared. Many of the victims of the state of terror were leaders of political parties of opposition, leaders of trade unions and student organizations, university and middle level professors, church-bound people, and journalists.

- On documents found in the same institution, there were 13 books of large format containing photographs of people arrested by the National Police. Usually, there was the photograph of the person, as well as the name, date, and crime the person was accused of.

- On these photographs, there are hundreds of men and women who were detained for political reasons, without any sign of doubt. In the photographs appears the name and then captions saying: "security measures", "subject to investigation", "subversive activities" and "guerrilla fighter".

- We, the AHPN, have always wondered if those people are part of 45,000 detained and disappeared persons.

- In another department of the $\mathrm{Na}$ tional Police, known as the Joint Operation Center, which was the one that had direct relationship with the army, documents have been found which state that a person was captured, then "identified" as subversive and therefore delivered to the army.

- Here two facts stand out; the first one is the actual disappearance of the person, and the second one is how the State agents violated the due legal process.

- We continue to have a State not committed to the truth and justice, except for honorable exceptions. The Congress of the Republic has refused to approve the Law Initiative 35-90, that dates from 2005, which declares the creation of the National Commission to Search for Victims of Forced Disappearance, for a country where 45,000 
families are unaware of the whereabouts of one or more than one of their loved ones.

- The Constitutional Court, the highest court of the country, annulled the sentence that condemned the General Efrain Rios Montt, ten days after it was issued. Rios Montt is the main character that incarnates the figure of the genocide committed in Guatemala.

- The AHPN lately has coined the concept of TRILOGY. The first component consists of the testimonies of the surviving victims and their families; through them the dimension and depth of the tragedy experienced by the civilian population began to be known. The second component refers to the scientific evidence provided by forensic anthropology. And the third component is related to the documentary evidence provided by the State archives.

- If we have a testimony, bones scientifically identified, and documents of the State that refer to the facts, we have solid cases to be brought to justice.

- Just in the center of the building where the AHPN is located, the $\mathrm{Na}$ tional Police operated a clandestine prison known as "La Isla". There is absolute physical evidence on how the National Police isolated the center of those facilities, only leaving a single entrance at the back of the facilities.

- On that area of the building, serious violations to human rights were committed. An analysis of the crime scene was done; however, there was not any more evidence (i.e., bones or clothes). As it was explained earlier, the State tried to conceal those facts by burying the victims in public cemeteries. This did not only happen in Guatemala City; it was also a pattern of action repeated hundreds of times in public cemeteries, in the interior of the country, and in military installations.

In conclusion, although many members of the army and conservative sectors speak of excesses, abuses and specific situations that gave rise to isolated acts of political violence committed by agents of the State -or openly deny genocide- today, there is scientific evidence-bones and archives of the State, added to the testimonies of the victims-proving without doubt that the State of Guatemala conceived, planned and executed a strategy of extermination, genocide, terror, torture, rape, and extrajudicial executions. It was a strategy that included, on a large scale, the cruel practice of enforced disappearance.

San José, Costa Rica, November 2016. 